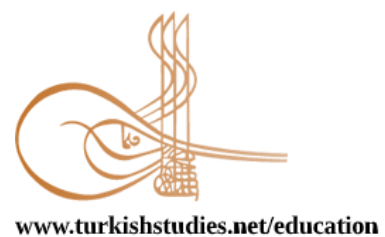

Turkish Studies - Educational Sciences

eISSN: 2667-5609

Research Article / Araștırma Makalesi

\title{
Bosna Hersek Federasyonu Tuzla Üniversitesi Türkoloji Bölümü Öğrencilerinin Yaptıkları Türkçe Biçim Bilgisel Sapmalar
}

\author{
Turkish Morphological Deviations Made by Students at Turcology Department of Tuzla University \\ in Bosnia Herzegovina Federation
}

\begin{abstract}
Ahmet Şahbaz*
Abstract: Morphology is very significant in Turkish which is known as the most typical example of agglutinative languages. Morphology is closely related to phonology, syntax and semantics and it is considered as the backbone of Turkish language by leading Turcologists. Therefore, it is really important to teach morphology of Turkish not only to native speakers but also to foreigners. Teaching Turkish as a foreign language has gained importance in recent years. That task is carried out by Turkish Teaching Centers in Turkey and by Yunus Emre Institute and Ministry of National Education abroad. The Turcology departments abroad are supported by these institutions in terms of material and teaching staff. This study was carried out in the Turkish Language and Literature Department of Tuzla University in the Federation of Bosnia and Herzegovina. A total of 46 students from the first, second, third and fourth grades participated in the study. The aim of the study is to identify the morphological deviations from standard Turkish. For this, face-to-face and individual interviews were conducted with students in accordance with the semi-structured interview technique. These interviews were recorded with a voice recorder and then these recordings were transcribed. Finally, the morphological deviations in these records were identified and classified under certain headings. As a result of the study, it was determined that the students had serious problems especially in the correct use of the case and possessive suffixes, the choice of correct tense and the correct use of derivational noun suffixes . It is thought that the data obtained here will shed light on the material and curriculum that will be prepared for teaching Turkish as a foreign language.
\end{abstract}

Structured Abstract: Introduction Morphology, the basic description of which is the study of roots and affixes is very import in Turkish language because it is known as the most typical example of agglutinative languages. In Turkish it is possible to create new words and even sentences by adding affixes to the roots of the words. Let's take the verb root gel- as an example. By attaching suffixes to this root we are able to make a sentence like "Gelmeyeceğim." This sentence was formed by attaching negative marker $-m X$ and future tense marker $-(y) A c A k$ and finally 1 st person singular marker $-X m$. This sentence is expressed as "I will not come" in English and "Ich werde nicht kommen" in German. As can be seen in this example below we need to use one word for each suffix in English and German

\footnotetext{
* Öğr. Gör. Dr. Muğla Sitkı Koçman Üniversitesi, Yabancı Diller Yüksekokulu. Lect. Mugla Sitki Kocman University, School of Foreign Languages ORCID 0000-0003-0367-6375 asahbaz1@hotmail.com

Cite as/ Atıf: Şahbaz, A. (2020). Bosna Hersek Federasyonu Tuzla Üniversitesi Türkoloji Bölümü öğrencilerinin yaptıkları Türkçe biçim bilgisel sapmalar. Turkish Studies - Education, 15(3), 2063-2084. https://dx.doi.org/10.29228/TurkishStudies.42800

Received/Geliş: 08 April/Nisan 2020

Accepted/Kabul: 21 June/Haziran 2020

Copyright (C) INTAC LTD, Turkey

Checked by plagiarism software

Published/Yayın: 25 June/Haziran 2020

CC BY-NC 4.0
} 


$\begin{array}{lccc}\text { Gel } & \text { me } & \text { yeceğ } & \text { im } \\ \text { I } & \mid & \text { will } & \text { I } \\ \text { come } & \text { not } & \text { will } & \text { Ich } \\ \text { kommen } & \text { nicht } & \text { werde } & \text {. }\end{array}$

This example shows us the significance of morphology in Turkish. According to some leading Turcologists morphology is believed to be the backbone of Turkish language. For example Ergin (1987:208) states that Turkish has a very rich suffixation system and he believes that examining grammar of Turkish is to examine this suffixation system. Therefore, when teaching Turkish to foreigners, morphology of this language should be paid more attention. Teaching Turkish as a foreign language has gained importance in recent years depending on the economic development of Turkey in its region. Many university students from other countries come to Turkey to study and they learn Turkish at Turkish Teaching Centers (TÖMER) of universities. That task is carried out by Yunus Emre Institute and Ministry of National Education abroad. There are many Turcology departments at universities abroad and they are supported by these Institutions in terms of material and teaching staff. As it was stated above, morphology is vital and should be taught well to foreign students. However, there are not sufficient studies on this subject in the literature. Therefore, this study was conducted in order to fill this gap. The study was carried out in the Turkish Language and Literature Department of Tuzla University in the Federation of Bosnia and Herzegovina. It aims to find out the morphological deviations made by the students. The research question of the study is: "What types of morphological deviations do the students of Turcology department make from standard Turkish?"

\section{Method}

This is a descriptive study and conducted at Turcology Department of Tuzla University to find out the Turkish morphological deviations made by the students. A total of 46 students, 11 first grade, 10 second grade, 12 third grade, 13 fourth grade participated in the study. 44 of 46 students are females and 2 are males. The reason for the low number of male students is that females generally prefer Turkish Language Literature Department. The ages of the participants vary between 19 and 23. The data in the study were obtained by using semi-structured interview technique in accordance with the qualitative research method. After the approval of the ethics committee, individual and face-to-face interviews were made with the students. During the interviews 18 questions prepared by the researcher were asked to the students and their answers were recorded. These questions were generally aiming to find out participants' attitudes towards Turkish. In order to analyze the data, first recordings were transcribed and the morphological deviations were identified.

\section{Findings and Discussion}

The identified deviations were grouped under the following main headings.

1. Deviations in noun inflections

2. Deviations in verb inflections

3. Deviations in derivational morphemes

4. Deviations in verbals

Turkish Studies - Education, 15(3) 
Bosna Hersek Federasyonu Tuzla Üniversitesi Türkoloji Bölümü Öğrencilerinin Yaptıkları... 2065

The subheadings of the main headings were shown in the table below.

\begin{tabular}{|c|c|c|c|c|c|}
\hline \multirow[t]{2}{*}{ The type of morphological deviation } & \multirow{2}{*}{$\begin{array}{l}\text { The total } \\
\text { number of } \\
\text { deviations }\end{array}$} & \multicolumn{4}{|c|}{$\begin{array}{l}\text { The number of deviations in each } \\
\text { class }\end{array}$} \\
\hline & & $\begin{array}{l}1 \text { st } \\
\text { grade }\end{array}$ & $\begin{array}{l}\text { 2nd } \\
\text { grade }\end{array}$ & $\begin{array}{l}\text { 3rd } \\
\text { grade }\end{array}$ & $\begin{array}{l}\text { 4th } \\
\text { grade }\end{array}$ \\
\hline 1-Omission of plural suffix -1Ar & 1 & & 1 & & \\
\hline 2- Unnecessary use of plural suffix & 5 & & 3 & & 2 \\
\hline 3-Omission of dative case marker $-(\mathrm{y}) \mathrm{A}$ & 4 & & & 1 & 3 \\
\hline 4-Omission of accusative case marker -(y) X & 27 & 6 & 4 & 6 & 11 \\
\hline 5- Misplacing of case markers & 20 & 2 & 10 & 5 & 3 \\
\hline 6- Omission of instrumental case marker -(y) $1 \mathrm{~A}$ & 4 & & & 3 & 1 \\
\hline 7- Omission of genitive case marker - (n) In & 4 & 1 & & 1 & 2 \\
\hline $\begin{array}{l}\text { 8- Omission of genitive case marker and possessive } \\
\text { suffix }\end{array}$ & 1 & & & 1 & \\
\hline 9- Omission of ablative case marker - DAn & 2 & & & & 2 \\
\hline 10-Unnecessary use of case suffixes & 1 & & 1 & & \\
\hline 11- Misapplication of possessive construction & 1 & & 1 & & \\
\hline 12- Omission of possessive suffix & 20 & 2 & 2 & 3 & 13 \\
\hline 13-Unnecessary use of possessive suffix & 3 & & 2 & & 1 \\
\hline 14-Omission of copular & 1 & & & & 1 \\
\hline 15-Unnecessary use of copular & 1 & & & 1 & \\
\hline 16-Omission or wrong use of personal suffix & 5 & 1 & 1 & & 3 \\
\hline 17-Wrong tense choice & 11 & & 4 & & 7 \\
\hline 18-Omission of modal of ability & 3 & & & 2 & 1 \\
\hline 19-Omission of conditional & 3 & & & 3 & \\
\hline 20-Omission of compound tense & 3 & & 1 & 1 & 1 \\
\hline 21-Omission of productive derivational suffix & 10 & 2 & 2 & 5 & 1 \\
\hline 22-Omission of voice suffix & 1 & & 1 & & \\
\hline 23-Misplacing of gerunds & 4 & & & 2 & 2 \\
\hline 24-Misuse of participles & 2 & & & 1 & 1 \\
\hline The number of total deviation & 137 & 14 & 33 & 35 & 55 \\
\hline
\end{tabular}

The findings of this study are compatible with the findings of previous studies. For example, Karababa (2009:273) stated that case suffixes are the most challenging area for foreign students to learn. In his study, Özkan (1994:40) identified 5 types of morphological deviations which are as follows:

1. Omission of case suffix, $\% 52,7$

2. Unnecessary use of case suffix, $\% 21,9$

3. Misplacing of case markers, $\% 25,4$

4. Not being able to use case suffixes compatible with vowel harmony

5. Unnecessary use of case suffixes in the subject of the sentence

Finally, Şahbaz (2018: 423) conducted a study with adult English Turkish bilinguals to find out the Turkish morphological deviations they made when speaking Turkish. His findings are as follows;

1. Nearly half of the participants are not able to use plural suffix $-1 \mathrm{Ar}$

2. They have difficulties in the correct use of case suffixes

3. They have problems with appropriate use of possessive suffix

4. They are not able to use copular correctly

5. They are not able use the personal suffixes correctly

6. They have difficulty in using modals, tense markers and personal suffixes in the correct order 
7. They have difficulty in the correct use derivational and voice suffixes.

As can be seen the findings of this study are compatible with the previous studies. The morphology especially suffixation system of Turkish seems a big problem for foreigners.

\section{Conclusion and Recommendations}

24 types of morphological deviation were identified. The total number of morphological deviation was shown for each class in the table above. In the table it is seen that the total number of morphological deviations is the highest for $4^{\text {th }}$ grade students which seems strange to us. It is not because their Turkish level is lower than $1^{\text {st }}$ grade students; it is because they spoke more than 1st grades in the interviews. There is a parallel correlation between amount of speaking time and morphological deviations.

Results shows us that the highest morphological deviation was made in case suffixes, possessive suffixes, tense choice, derivational suffixes, compound tenses, voice suffixes and verbals respectively. The similar results were obtained in the previous studies made by Karababa, Özkan, Kara, Şahbaz. Therefore, more attention and time should be allocated to these subjects when teaching Turkish as a foreign language.

It is thought that the data obtained here will shed light on the material and curriculum that will be prepared for teaching Turkish as a foreign language.

Key Words: Teaching Turkish as a foreign language, morphology, deviations, Bosnia- Herzegovina, Turcology

Öz: Sondan eklemeli dillerin en tipik örneği olarak bilinen Türkçede biçim bilgisi oldukça önemlidir. Ses bilgisi, söz dizim ve anlam bilim ile sıkı bir ilişki içinde olan biçim bilgisi önde gelen birçok Türkolog için Türkçenin bel kemiğini oluşturmaktadır. Bu sebeple, Türkçenin biçim bilgisinin gerek ana dili konuşurlarına gerekse yabancılara öğretilmesine özel önem verilmelidir. Son yıllarda Türkçenin bölgesinde ekonomik bir güç olarak ortaya çıkmasıyla birlikte yabancı dil olarak öğretimi önem kazanmıştır. Türkçenin yabancı dil olarak öğretimi işini, yurt içinde Türkçe Öğretim Merkezleri (TÖMER); yurt dışında ise Yunus Emre Enstitüsü ve Milli Eğitim Bakanlığı yürütmektedir. Bu kurumlar gerek malzeme gerekse öğretim elemanı konusunda yurt dışında bulunan üniversitelerin Türkoloji bölümlerine destek vermektedir. Bu çalışma Bosna Hersek Federasyonu, Tuzla Kantonunda bulunan Tuzla Üniversitesi Türk Dili ve Edebiyatı bölümünde gerçekleştirilmiş̧tir. Çalışmaya birinci, ikinci, üçüncü ve dördüncü sınıflardan toplam 46 öğrenci katılmıştır. Çalışmanın amacı öğrencilerin konuşurken standart Türkçeden yapmış oldukları biçim bilgisel sapmaları tespit etmektir. Bunun için yarı yapılandırılmış görüşme tekniğine uygun olarak öğrenciler ile yüz yüze ve tek tek görüşmeler yapılmıştır. Bu görüşmeler ses kayıt cihazı ile kayıt altına alınmış ve daha sonra da bu kayıtlar yazıya dökülmüştür. Son olarak yazıya dökülen bu kayıtlardaki biçim bilgisel sapmalar tespit edilmiş ve belirli başlıklar altında sınıflandırılmıştır. Çalışma sonucunda öğrencilerin özellikle ad durum ve iyelik eklerinin doğru kullanımı, zaman seçimi, addan ad yapım eklerinin doğru kullanımı konularında ciddi sorunlar yaşadıkları tespit edilmiştir. Buradan elde edilen verilerin Türkçenin yabancı dil olarak öğretimi için hazırlanacak olan materyal ve müfredata 1şık tutacağı düşünülmektedir.

Anahtar Kelimeler: Yabancı dil olarak Türkçe öğretimi, biçim bilgisi, sapmalar, Bosna Hersek, Türkoloji

\section{Giriş}

En basit şekliye kelimelerin kök ve eklerini inceleyen dil bilgisel alan olarak tanımlanan biçim bilgisi, Türkçenin dil bilgisi üzerine uzun yıllar çalışmış ve bu alanda önemli eserler vermiş Türkologlar tarafından çeşitli şekillerde tanımlanmıştır. Ergin'e göre (1987: 69) biçim bilgisi; "dil bilgisinin kelime ve şekillerin, kelimelerin, köklerin ve eklerin yapısını ve fonksiyonunu inceleyen bölümüdür." Korkmaz (2014: 99) biçim bilgisini; bir dilin kök kelimelerini, eklerini, köklerle eklerin birleşme yollarını, eklerin anlam ve görevlerini, türetme ve çekim özelliklerini ve şekille ilgili öteki konularını inceleyen gramer dalı olarak tanımlamış ve biçim bilgisinin temel ögelerinin kelime kökleri ve ekleri olduğunu ifade etmiştir. Korkmaz'a göre (2014: 99) biçim bilgisi "Bir yandan dilin şekilden anlama, kelimeden sözcük birimlerine, bir yandan da türetme, birleştirme, kalıplaşma, anlam kayması, anlam dallanması gibi çok çeşitli ve kapsamlı dil olayları ile cümle, 
anlam ve köken bilgilerine uzanan temel dayanağ 1 niteliğindedir ve dilin bel kemiğini oluşturur.“ Banguoğlu (1986:5) Türkçenin Grameri adlı eserinde biçim bilgisi için yapı bilgisi terimini kullanmış ve yapıbilgisinin (morphologie), kelimelerin yapısını, bunların uğradıkları anlam ve ilişki değişikliklerini gösterdiğini belirtmiş̧ir. Demir (2015: 3) biçim bilgisini; dilbilgisi ve dilbilimin, dildeki anlamlı ve işlevli en küçük birimler olan kelimelerin yapı, işlev ve kullanımını inceleyen kolu olarak tanımlamıştır. Demir'e (2015: 3) göre biçim bilgisi; ses bilgisi, söz dizimi ve anlam bilimi ile birlikte dil bilgisinin temel birimlerinden biri olup bu alanlarla sıkı bir işbirliği içindedir. Balcı'ya göre (2012: 19) dilbilimin bir alt dalı olan biçim bilim anadili kullanıcılarının sözcük düzeyine ilişkin sezgisel bilgilerinin betimlemesini yapar ve bu bilim dalı; sözcükler, sözcüklerin, yapısı, sözcüklerin sınıflandırılması, sözcüklerin türetilmesi ile tüm bunları yöneten kuralları içeren zihinsel süreçleri inceler. Demirci (2014:110) biçim bilgisinin bir bilim alanı olarak dildeki unsurların hangi parçacıklardan yapıldığını gösterdiğini ve sesin bir üst seviyesi olan kökler ve ekler konusunu incelediğini belirtmiştir. Erdem ise (2009: 92) kelimelerin anlamları ve biçimleri arasında sistemli bir düzenlilik göze çarptığına dikkat çekmiş ve dilbilimin önemli bir kolu olan biçim bilgisinin kelimelerin bu düzenli biçimlerinin içyapılarını incelediğini yani biçim bilgisinin kelimelerin içyapılarıyla, sözlük birimlerin biçimleriyle ve kelime yapımıyla ilgilendiğini ifade etmiştir.

Literatüre bakıldığında biçim bilgisi, dil bilgisi kitaplarında genel olarak kelime yapısı, kelime yapımı gibi başlıklar altında ele alınmıştır. Çalışmalarda, genellikle kelimelerin şekil yapıları kökler ve ekler olmak üzere iki başlık altında toplanmaktadır. Kökler isim kökleri ve fiil kökleri; ekler ise yapım ve çekim ekleri olarak iki kısma ayrılmaktadır. Yapım eklerinin isimden isim yapım ekleri, isimden fiil yapım ekleri, fiilden fiil yapım ekleri ve fiilden isim yapım ekleri; çekim eklerinin ise isim çekimleri ve fiil çekimleri olarak sınıflandığını görürüz. Bu sınıflandırma şu şekilde gösterilebilir.

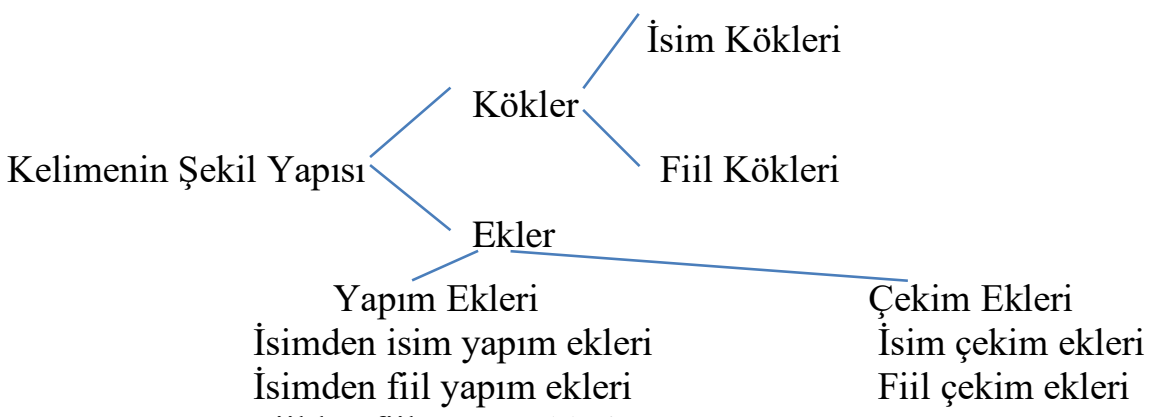

Fiilden fiil yapım ekleri

Fiilden isim yapım ekleri

Yukarıdaki şekilde de gösterildiği gibi kelimenin şekil yapısının en temel iki ögesi kökler ve eklerdir. Literatürde, kök ve ek kavramları araştırmacılar tarafından farklı şekillerde tanımlanmıştır. Örneğin, Ergin (1987:208) kökleri kelimenin manalı parçaları; ekleri de kelimenin vazifeli parçaları olarak tanımlamıştır. Ayrıca Ergin (1987:208) Türkçenin çok zengin bir ekler sitemine sahip olduğunu belirtmiş ve Türkçenin gramerini incelemenin bu ekler sitemini incelemek olduğunu ifade etmiştir. Korkmaz (2014:101) kelimelerin şekil yapıları incelendiğinde içlerinde anlamlı ögeler ile görevli ögelerin yer aldığını ve kelimelerde yer alan anlamlı ögelerin kökler, görevli ögelerin de ekler olduğunu belirtmiştir. Korkmaz (2014: 102-106) kökleri kelimelerin yapısında yer alan bütün ekler çıkarıldıktan sonra, daha küçük parçalara ayrılamayan, kelimelerin temel anlamını oluşturan ögeler; ekleri ise, kelimenin yapısında yer alan, tek başına kullanılmayan, kökler ile birleşerek gövdeler, gövdeler ile birleşerek yeni kelime gövdeleri yahut kelimeler arasında geçici anlam ilişkileri kuran görevli şekiller olarak tanımlamıştır. Korkmaz da (204:106) Ergin ile benzer biçimde Türkçenin eklemeli bir dil yapısında olduğundan, gerek kelime yapımında gerek kelimeleri kullanım alanına çıkararak dilin işletilmesinde eklerin çok geniş ve önemli bir 
payı olduğunu belirtmiştir. $\mathrm{Bu}$ tespitine ek olarak da, Türkiye Türkçesinin yapısını iyi kavrayabilmek için ondaki ek sisteminin yapı ve işleyiş özelliklerini de iyi bilmek gerektiğinin altını çizmiştir. Banguoğlu (1986:111) kök kavramını sözlük kelimelerinden bölünemez anlam unsurları olarak tanımlamıştır. Kökleri isim ve fiil kökleri; ekleri ise çekim ekleri ve üretim ekleri olarak sınıflandırmıştır. Gencan (1979: 57 ) kökleri; kök sözcükler olarak adlandırmış ve kök sözcükleri de başka sözcüklerden ekle ya da bileşme yoluyla türememiş, yapılmamış sözcükler olarak tanımlamış ve onlara yalınç sözcükler de denilebileceğini ifade etmiştir. Kökleri de ad kökleri ve eylem kökleri olarak ikiye ayırmıştır. Aynı çalışmasında Gencan (1979: 59) ekleri sözcük türetmeye ya da sözcüklerin görevlerini belirtmeye yarayan parçalar olarak tanımlamış ve onları yapım ve çekim ekleri olarak ikiye ayırmıştır.

Bazı dil bilgisi uzmanları ekleri yukarıdaki sınıflandırmalardan farklı şekillerde ele almış ya da yukarıdaki tasniflere katkı sağlamışlardır. Örneğin Delice (2000:222) çalışmasında diğer araştırmacıların yaptıkları ek tanımlarını sıralamış, eklerin dilbilgisi kaynaklarında nasıl tasniflendiği belirtmiş ve kendi ek tanımını yapmıştır. Delice'ye göre (2000:222) ek "Tek başına anlamı olmayan ve kullanılmayan ancak kelime ile birleşmek suretiyle kullanılan ve eklendiği kelimenin kök anlamına değişik anlam ilgileriyle genişlik kazandıran, türünü değiştiren, onu başka bir kelimeye veya yükleme bağlayan ya da ondan yeni kelimeler üreten biçim birimlerdir." Aynı çalışmasında Delice (2000:232) Türkçede var olan tüm eklerin yedi ortak işlevi yerine getirmek için kullanıldıklarını belirtmiştir. Bu ekleri de geleneksel tasniflemeden farklı olarak genişletme ekleri, durum ekleri, kurucu ekler, dönüştürücü ekler, yapım ekleri, bütünleşik ekler ve temsil ekleri başlıkları altında toplamıştır. Başdaş'da (2006:5) eklerin birçok kaynakta yapım ekleri ve çekim ekleri olarak ikiye ayrıldığını ancak bütün yapım eklerinin kelimenin türünde ve anlamında aynı oranda değişiklik yapmadığını; bütün çekim eklerinin de her zaman ve sadece kelimeler arasında anlam ilişkisi kurmadığını ifade etmiştir. Başdaş'a (2006:5) göre "Bilinen en eski metinlerde, bazı yapım ve çekim eklerinin fonksiyonları birbirine yakındır. Bir kısmının işlevi ise, tarihî süreç içinde birbirine yaklaşmış ve birçok noktada kesişmiştir. Bu sebeple Türkçede kullanılan yapım ve çekim eklerini, eşit uzaklıktaki iki ayrı nokta üzerinde düşünüp kesin çizgilerle birbirinden ayırmak pek mümkün görünmemektedir." Bu sebeple, Başdaş (2006:5) ara eklerden bahsetmiş, işlev ve kullanılışları bakımından yapım ekleriyle çekim eklerinin kesişme noktasında bulunduğunu düşündüğü ara ekleri şu şekilde sıralamıştır. İsim-fiil ekleri, sıfat-fiil ekleri, zarf-fiil ekleri, çatı ekleri, olumsuzluk eki (-mA), çokluk eki (+1Ar), eski yön gösterme eki (-GArU), eski vasıta eki $+($ I $)$ n ve eşitlik eki + ÇA.

Yapısal olarak sondan eklemeli dillerin en tipik örneği olan Türkçenin biçim bilgisinin doğru anlaşılması oldukça önemlidir çünkü Türkçede kelime köklerine yapım ekleri getirilerek yeni kelimeler türetilebilir; çekim ekleri getirilerek te kelimeler arasında geçici ilişkiler kurulabilir. Örneğin Türkçe gel- köküne olumsuzluk eki $m X$, gelecek zamana eki $-(y) A c A k$, ve birinci tekil şahıs eki -Xm eklenerek "Gelmeyeceğim." şeklinde bir cümle kurulabilir. Bu durum Hint Avrupa dil ailesine mensup olan İngilizce ve Almanca için geçerli değildir. Bu cümle İngilizcede "I will not come" Almancada "Ich werde nicht kommen" şeklinde ifade edilir.

$\begin{array}{lccc}\text { Gel } & \text { me } & \text { yeceğ } & \text { im } \\ \text { I } & \mid & \mid & \mid \\ \text { come } & \text { not } & \text { will } & \text { I } \\ \text { kommen } & \text { nicht } & \text { werde } & \text { Ich }\end{array}$

Türkçede göz sözcügüne yapım ekleri getirerek yeni sözcükler türetebiliriz (Göz-lük-çülük). Bu örneği, İngilizce ile kıyasladığımızda Türkçede kelime köküne yapım eki getirerek türettiğimiz her sözcük için İngilizcede farklı sözcükler kullanıldığını görürüz.

opticianary

göz: eye gözlük: glasses gözlükçü: optician gözlükçülük: 
Burada sadece opticianary sözcügünün optician sözcügünden türediği diğer sözcüklerin ise bağımsız sözcükler olduğu görülmektedir.

Hint Avrupa dil ailesinin Slav koluna mensup olan Boşnakçada da dil işleyiş mantığı İngilizce ve Almancadakine benzerdir. Bu çalışmada Türkçeyi yabancı dil olarak öğrenen ve Türk dili ve edebiyatı okuyan Boşnak öğrencilerin Türkçe konuşurken biçim bilgisel anlamda ne tür sapmalar yaptıkları üzerinde durulacaktır. Son yıllarda Türkçenin yabancı dil olarak öğretilmesi konusu ciddi oranda önem kazanmıştır. Araplara Türkçe öğretmek amacıyla Kaşgarlı Mahmut tarafından 1072-1077 yılları arasında yazılmış Divan-1 Lügati’t Türk ile başlayan süreç günümüzde de devam etmektedir. Bu işi ülkemizde üniversitelerde Türkçe Öğretim Merkezleri (TÖMER), yurt dışında ise Yunus Emre Enstitüsü ve Milli Eğitim Bakanlığı yürütmektedir. Dünyanın birçok üniversitesinde Türkoloji bölümleri bulunmaktadır ve bu bölümlerde Türk dili, edebiyatı, kültürü ve tarihi öğretilmektedir. Dünyadaki Türkoloji bölümlerinin daha iyi hizmet verebilmesi adına Türkiye Cumhuriyeti Devleti çeşitli şekillerde bu bölümlere destek sağlamaktadır. Bu destek Türkiye İşbirliği ve Koordinasyon Ajansı (TiKA) Başkanlığı, Yunus Emre Enstitüsü ve Milli Eğitim Bakanlığı üzerinden verilmektedir. Bu kurumlar Türkoloji bölümlerine malzeme, materyal, kitap ve öğretim elemanı noktasında katkı sağlamaktadır.

Türkiye Cumhuriyet Devleti açısından tarihsel ve kültürel anlamda büyük bir öneme sahip olan Bosna Hersek'te Saraybosna, Tuzla, Zenica ve Mostar'daki devlet üniversitelerinde Türkoloji bölümleri bulunmaktadır. Bosna Hersek Federasyonu'nun kuzeyinde bulunan Tuzla Kantonu, Saraybosna ve Banja Luka'dan sonraki üçüncü büyük kantondur. Kantonla aynı adı taşıyan Tuzla Üniversitesi Felsefe Fakültesi bünyesinde 2002 y1lında Türkiye Cumhuriyeti Devleti'nin desteği ile Türk Dili ve Edebiyatı bölümü kurulmuştur. 2002 yılında 37 öğrenci ile öğretim vermeye başlayan bölüm 2005/2006 en yüksek öğrenci sayısı olan 144'e ulamış ve bu yükseliş trendi 2015 yılına kadar devam etmiştir. 2015 yılından sonra öğrenci sayılarında hafif bir düşme eğilimi olmuştur. Bu düşüş sadece Türkoloji için geçerli olmayıp, diğer birçok bölüm içinde geçerlidir. Bunun sebebi son birkaç yılda Bosna Hersek'te yaşayan genç nüfusun Almanya tarafindan istihdam edilmesi ve liseyi bitiren gençlerin üniversiteye gitmek yerine Almanya'ya gitmeyi tercih etmeleridir.

2019/2020 eğitim ve öğretim itibari ile Tuzla Üniversitesi, Felsefe Fakültesi, Türk Dil ve Edebiyatı bölümü 65 öğrenci ile öğretimine devam etmektedir. Bölümde okuyan tüm öğrencilerin anadili Boşnakçadır. Bilindiği üzere Türkçe ve Boşnakça farklı dil ailelerine mensup olan dillerdir. Boşnakça Hint-Avrupa dil ailesinin Slav koluna, Türkçe ise Ural-Altay dil ailesinin Altay koluna bağlıdır. Hint-Avrupa dilleri çekimli, Ural-Altay dilleri ise eklemelidir. Bu iki dil tipolojik olarak birbirinden farklılıklar göstermektedir. İki dil arasındaki bu tipolojik farklılıklar Boşnak öğrencilerin yazarken ve özellikle de konuşurken hatalar yapmalarına neden olabilmektedir. Öğrenciler bazı durumlarda kendi dil yapılarını aynı şekliyle Türkçeye transfer etmekte bu da onların ses bilgisel, biçim bilgisel, söz dizimsel ya da anlam bilimsel hatalar yapmalarına yol açabilmektedir.

\section{Çalışmanın amacı}

Bu çalışmada Bosna Hersek Federasyonu'nda bulunan Tuzla Üniversitesi Türk Dili ve Edebiyatı bölümünde okuyan birinci, ikinci, üçüncü ve dördüncü sınıf öğrencilerinin konuşurken standart Türkçeden yapmış oldukları biçim bilgisel sapmalar tespit edilmeye çalışılmıştır.

\section{Çalıșmanın önemi}

Literatüre bakıldığında Bosna Hersek’teki Türkoloji öğrencilerin yapmış oldukları Türkçe biçim bilgisel sapmalar ile ilgili çalışmaya rastlanmamıştır. Bu çalışma Tuzla Üniversitesi Türkoloji bölümünde okuyan öğrencilerin yapmış oldukları biçim bilgisel sapmaların tespit edilmesi açısından önemlidir. 


\section{Yöntem}

\section{Araştırma sorusu}

Tuzla Üniversitesi Türk dili ve edebiyatı okuyan öğrenciler konuşurken standart Türkçeden ne tür biçim bilgisel sapmalar yapmaktadır?

\section{Araştırma modeli}

Çalışma tanımlayıcı/ betimsel bir çalışmadır. Çalışmada, Tuzla Üniversitesi Felsefe Fakültesinde okuyan öğrencilerin Türkçe konuşurken yapmış oldukları biçim bilgisel sapmalar ortaya çıkarılmaya çalış1lacaktır.

\section{Katılımci grubu}

Çalışmaya 11 birinci sınıf, 10 ikinci sınıf, 12 üçüncü sınıf, 13 dördüncü sınıf olmak üzere toplam 46 öğrenci katılmıştır. 46 öğrencinin 44'ü kız, 2'si de erkektir. Erkek öğrenci sayısının az olmasının sebebi Türk Dili Edebiyatı bölümünü genel olarak kızların daha çok tercih ediyor olmasıdır. Katılımcıların yaşları 19 ile 23 arasında değişiklik göstermektedir. Bu çalışma, Tuzla Üniversitesi Rektörlüğünden 26.12.2018 tarinde alınan 02/5-7145.18/18 sayılı etik kurul onayından sonra başlatılmıştır.

\section{Veri toplama araçları}

Çalışmada yer alan veriler nitel araştırma yöntemine uygun olarak yarı yapılandırılmış görüşme tekniği kullanılarak elde edilmiştir. Alınan etik kurul izni sonrası öğrencilerle tek tek ve yüz yüze görüşmeler yapılmıştır. Katılımcıların verdikleri cevaplar ses kayıt cihazı ile kayıt altına alınmıştır. Görüşme soruları araştırmacı tarafindan hem Türkçe hem de Boşnakça olarak öğrencilere mülakat yapılmadan 2 hafta önce dağıtılmış ve öğrencilerden bu sorular üzerinde düşünmeleri ve bu soruları cevaplamaları istenmiştir. Yapılan görüşmelerde kullanılan dil Türkçedir ancak özellikle birinci sınıf öğrencileri içinde Türkçesi iyi olmayan öğrenciler bulunmaktadır. Bu sebeple birinci sınıf öğrencileri sorulan sorulara daha kısa cevaplar vermişlerdir. Görüşme yapılırken öğrencilerin önüne görüşme sorularının hem Türkçe hem de Boşnakça formları konulmuş öğrenciler her ikisine bakarak soruları cevaplamaya çalışmışlardır. Her bir öğrenci ile yapılan görüşmeler 10 ile 12 dakika arasında sürmüştür. Öğrencilere yapılan görüşmelerde aşağıdaki sorular sorulmuştur.

\section{Görüşme soruları}

1. Adınız ve soyadınız nedir?

2. Kaç yaşındasınız?

3. Hangi dilleri biliyorsunuz?

4. Türkçe ile ilk ne zaman karşılaştınız?

5. Türkçe ile ilk defa nasıl karşılaştınız?

6. Türkçe zor bir dil mi?

7. Türkçede en zor dilbilgisi konusu nedir?

8. Türkçede en kolay dilbilgisi konusu nedir?

9. Türkçe söylemekte zorlandığınız sesler nelerdir?

10. Neden Türkçe öğreniyorsunuz?

11. Bir günde kaç saat Türkçe konuşuyorsunuz?

12. Ders dışında arkadaşlarınızla kaç saat Türkçe konuşuyorsunuz? 
13. Ailenizde sizden başka Türkçe bilen var mı?

14. Aileniz sizi Türkçe öğrenmeniz konusunda teşvik ediyor mu?

15. Arkadaşlarınıza Türkçe öğrenmelerini tavsiye ediyor musunuz?

16. Arkadaşlarınıza bu bölümde okumalarını tavsiye eder misiniz?

17. Neden bu bölümü seçtiniz?

18.Okulu bitirince ne yapmayı düşünüyorsunuz?

\section{Verilerin çözümlenmesi}

Öncelikle görüşmelerin ses kayıtları yazıya geçirilmiştir daha sonra yazıya geçirilen bu kayıtlarda bulunan biçim bilgisel sapmalar tespit edilmiştir. Tespit edilen bu sapmalar aşağıdaki ana başlıklar ve onların alt başlıkları altında öğrencilerin sınıflarına göre gruplandırılmıştır.

1. Ad çekimi ile ilgili sapmalar

2. Fiil çekimi ile ilgili sapmalar

3. Yapım ekleri ile ilgili sapmalar

4. Fiilimsiler ile ilgili sapmalar

\section{Bulgular ve Tartışma}

\section{Ad çekimi ile ilgili sapmalar} toplanmıştır:

Elde edilen verilerin çözümlenmesi sonucu ad çekimi ile ilgili sapmalar şu başlıklar altında

1. Çoğul ekleri ile ilgili sapmalar

2. Ad durum ekleri ile ilgili sapmalar

3. İyelik ekleri ile ilgili sapmalar

4. Bildirme çekimi ile ilgili sapmalar

5. Çekimde kullanılan kişi ekleri ile ilgili sapmalar

\section{1. Çoğul ekleri ile ilgili sapmalar}

\section{Çoğul ekinin kullanılmaması}

\section{Sınıflara göre sapma örnekleri:}

A: Türkçe öğrenirken seni zorlayan bir gramer konusu oldu mu?

B: Saat (Saatler) (2.sinıf)

Çoğul ekininin kullanılmaması ile ilgili sapma sayısı bir olarak karşımıza çıkmaktadır. Buradan yola çıkarak çoğul ekinin kullanılmamasının çok sık karşılaşılan bir sapma türü olmadığ1 sonucuna varılabilir.

\section{Çoğul ekinin gereksiz kullanımı}

\section{Sinıflara göre sapma örnekleri:}

Lisede çok diller (dil) okudum, Fransızca, Almanca, Latince (2.sınıf)

Çünkü çok kelimeler (kelime) bilmiyorum. (2.sınıf)

Burada bir butik açmak istiyorum çünkü ben klyafetleri (kıyafet) dikiyorum. (2.sınıf) 
Bir şirket var, perdeler (perde) yapıyorlar. (4.sinıf)

Türkiye'den ve İtalya'dan, birkaç ülkeler(ülkeden) erkeler ve kızlar geldiler.(4. Sınıf)

Çoğul ekinin gereksiz kullanımı ile ilgili yapılan sapma sayısı ikinci sınıflarda üç, dördüncü sınıflarda ise iki toplamda beş olarak karşımıza çıkmaktadır. Bu sapmanın birinci sınıflar tarafından yapılmamış olmasının sebebi, birinci sınıf öğrencilerinin çoğunun sorulan sorulara kısa cevaplar vermesi ve görüşmelerde diğer sınıflara göre daha az Türkçe konuşmasıdır.

\subsection{Ad durum ekleri ile ilgili sapmalar}

\section{Yönelme ekinin kullanılmaması -(y)A}

\section{Sınıflara göre sapma örnekleri:}

İlk defa felsefe fakültesi (fakültesine) kayıt olduğumda Türkçe ile karşılaştım(3.sınıf)

Çünkü liseden sonra hangi fakülte (fakülteye) gidebilirim diye düşündüm. (4.sınıf)

Ben Türkiye (Türkiye'ye) hiç gitmedim.(4.sınıf)

Türkiye (Türkiye’ye) gitmek istiyorum. (4.sinıf)

Yönelme ekinin kullanılmaması ile ilgili yapılan sapma sayısı üçüncü sınıflarda bir, dördüncü sınıflarda üç toplamda dört olarak karşımıza çıkmaktadır. Birinci ve ikinci sınıflarda bu sapma türüne rastlanmamıştır. Burada da dördüncü sınıf öğrencilerinin en fazla sapma yapan grup olduğu göze çarpmaktadır. Bunun sebebi dördüncü sınıf öğrencilerinin daha az Türkçe bilmeleri değil, diğer sınıflara göre görüşmelerde daha fazla Türkçe konuşmalardır. Konuşma süresi ve miktarı arttıkça yapılan sapma sayısı da paralel olarak artış göstermektedir.

\section{Belirtme ekinin kullanılmaması -(y) X}

\section{Sinıflara göre sapma örnekleri:}

Ben Türkçe (Türkçeyi) çok seviyorum ve öğrenmek istiyorum. (1.sınıf)

Türkçe (Türkçeyi) çok seviyorum. (1.sinı)

Türkçe (Türkçeyi) seviyorum. (1.sinıf)

Ben Türk dizileri (Türk dizilerini) alt yazılı izledim.(1.sınıf)

Türkçe (Türkçeyi) seviyorum. (1.sinıf)

Çünkü ben Türkçe (Türkçeyi) ve Türkiye (Türkiye'yi) çok seviyorum. (1.sınıf)

Türkçe (Türkçeyi) seviyorum. (2.sınıf)

Bilmiyorum vallahi çünkü Türkçe (Türkçeyi) seviyorum. (2.sınıf)

Ben o zaman ben 10 yaşındaydım ben ilk Türk dizileri (dizilerini) izledim. (2.sınıf)

Ben babaannemin Türk dizileri (Türk dizilerini) izledim. (2.sınıf)

A:En kolay neyi buldun?

B: $O(O n u)$ da bilmiyorum. (3.sinif)

Hatırlamıyorum şimdi yani başta saçma sapan hatalar yaptım yani konuşurken ne bileyim ekler (ekleri) öğrenirken. (3.sinıf)

Babam biliyor ama yani bazı gramer kuralları (kurallarını) biraz unuttu. (3.sinı)

Diziler (Dizileri) seyretmeye başladım. (3.sınıf) 
Bosna Hersek Federasyonu Tuzla Üniversitesi Türkoloji Bölümü Öğrencilerinin Yaptıkları... 2073

Bu bölüm seçtim çünkü İstanbul (İstanbul'u) seviyorum Türkiye'yi seviyorum o yüzden bu bölümü seçtim. (3.sinıf)

Diziler (Dizileri) seyretmeye başladım ve ondan sonra Türk Dili ve Edebiyatı (Türk Dili ve Edebiyatını) seçtim. (3.sınıf)

Türkçe hakkında düşünmeye başladım ve beğendim, dilini beğendim kültür (kültürünü) beğendim bunun için seçtim. (4.sınıf)

Türk yazarlardan sadece 2 tane tanıyorum çok tanıyorum ama aslında yani yeni yazarlardan Orhan Pamuk (Orhan Pamuk'u) taniyorum. (4.sinf)

Onun kitabı (kitabını) okuyorum. (4.sinf)

Ben ilk Kurtlar Vadisi (Kurtar Vadisini) izledim. (4.Sınıf)

İngilizce yani hayatım boyunca öğreniyorum ve Türkçe (Türkçeyi) 3 yıl önce öğrenmeye başladım. (4.sınıf)

Diziler (Dizileri) izliyordum ama Türkçe kursuna gitmedim. (4.sinıf)

Lise (Liseyi) bitirdikten sonra Türkçe okumak istiyordum. (4.sınıf)

Türkçe okumak için sınav (sınavı) geçtim işte şimdi Türkçe okuyorum. (4.sınıf)

O yüzden ben Türkçe (Türkçeyi) seçtim çünkü baştan öğrenmem lazım. (4.sınıf)

Evet diziler (dizileri) izledim.(4.sinıf)

Ondan sonra Türk Dili ve Edebiyatı (Edebiyatını) seçtim. (4.sınıf)

Belirtme ekinin kullanılmaması ile ilgili yapılan sapma sayısı birinci sınıflarda altı, ikinci sinıflarda dört, üçüncü sinıflarda altı, dördüncü sınıflarda ise on bir toplamda yirmi yedi olarak karşımıza çıkmaktadır. Burada dikkat çeken nokta birinci sınıf öğrencilerin bu alanda yaptıkları sapma sayılarının daha fazla olmasıdır. $\mathrm{Bu}$ durum öğrencilere sorulan "Neden Türkçe öğreniyorsunuz?" sorusuna öğrencilerin verdiği "Çünkü Türkçe seviyorum" cevabından kaynaklanmaktadır. Bu soruya verilen cevapta ad, belirtme ekini alması gerekirken bunun birinci sınıf öğrencilerinin bir kısmı tarafından kullanılamadığı görülmüştür. Birinci sınıf öğrencileri sorulara uzun cevaplar verdiklerinde yaptıkları sapma oranı da artmaktadır. Bu kısımda da, dördüncü sınıf öğrencileri en fazla sapma yapan grup olarak karşımıza çıkmaktadır. Bunun sebebi dördüncü sınıf öğrencilerinin görüşmelerde daha fazla Türkçe konuşmasıdır. Genel olarak bakıldığında ve diğer ad durum ekleri ile ilgili sapmalar ile karşılaştırıldığında belirtme ekinin kullanılmaması ile ilgili sapma sayısı oldukça yüksektir. Bu sebeple genelde ad durum eklerini öğretirken özellikle de belirtme ad durum ekini öğretirken daha dikkatli olunmalı, bu konu üzerinde daha fazla durulmalı, öğrencilere daha fazla alıştırma ve pratik yaptırılmalıdır.

\section{Ad durum eklerinin birbirinin yerine kullanılması}

\section{Sinıflara göre sapma örnekleri:}

Bir gün Türkiye'de (Türkiye’ye) gideceğim. (1.sınıf)

Evet, ben folklor oynuyorum, Izmir'de (İzmir'e) gitti. (1.sınıf)

Fakülteye (Fakülteden) önce hiç konuşmadım ama dizisi izledim. (2.sınıf)

Okula (okulda) çalışmak istemiyorum. (2.sınıf)

Ben babaannemin (babaannemle) Türk dizileri izledim. (2.sınıf)

Ben lisede Almanca ve İngilizce öğrendim ama ben bunları (bunlara) devam etmek istemedim. (2.sinıf)

www.turkishstudies.net/education 
Ben fakülteye (fakülteden) önce kurstan (kursa) giderim. (2.sınıf)

A: Lisedeyken mi?

B: Yok yok fakülteye (fakülteden) önce (2.sinıf)

Levent kurs adi orda (oraya) gitti. (2.sinif)

O yüzden fakülteye (fakültede) Türk dili okuyorum. (2.sınıf)

Ben orada (oraya) gittim böyle baktım yani (2.sınıf)

Ben ne yapacam bilmiyorum inşallah Türkiye'de (Türkiye'ye) gideceğim.(2.sınıf)

Üçüncü sınıfım ama ben bazı dersleri dördüncü sınıfta giriyorum yani bu hakkım var yani dördüncü sınıftan bazı dersleri (derslere) girmeye hakkım var. (3.sınıf) (3.sinif)

Evet, ben üniversitede (üniversiteye) gelince ben o zaman dizileri izlemeye başladım

Onlarda (Onlardan) duydum. (3.sinif)

Kursta (Kursa) yani Türk kursuna gittim. (3.sinıf)

Çocuklara (Çocuklarla) oynamayı seviyorum (3.sınıf)

Sen beni (bana) Boşnakça öğret. (4.sınıf)

Sadece söyleyince güneş bana (benim) çok hoşuma gidiyor. (4.sınıf)

Öğrenci Türkiye'den gelince bizimle kafede (kafeye) geldik. (4.sinıf)

Ad durum eklerinin birbirinin yerine kullanılması ile ilgili sapma sayısı birinci sınıflarda iki, ikinci sınıflarda on, üçüncü sınıflarda beş ve dördüncü sınıflarda üç toplamda yirmi olarak karşımıza çıkmaktadır. Burada dikkat çeken nokta ikinci sınıflarda bu alanda yapılan sapma sayısının diğer sınıflara oranla yüksek olmasıdır. Bundan önceki alanlarda olduğu gibi birinci sınıflardaki sapma sayısı düşüktür. Burada dikkat çeken diğer bir husus, dördüncü sınıf öğrencilerinin görüşmelerde daha fazla Türkçe kullanmalarına rağmen bu alanda yapmış oldukları sapma sayısının düşük olmasıdır.

\section{Araç ekinin kullanılmaması}

\section{Sınıflara göre sapma örnekleri:}

A: Kiminle?

S: Bazı arkadaşlar (arkadaşlarla). (3.sınıf)

Orada bir Türk (Türk'le) tanıştı ve evlendi. (3.sınıf)

Fakülteye gitmeye başladığımda gramere(gramerle) karşılaştım. (3.sınıf)

Biz Türkiye'den tanıştık bazı erkekler (erkelerle) ve ben beğendim Türkçeyi. (4.sınıf)

Araç ekinin kullanılmaması ile ilgili sapma sayısı üçüncü sınıflarda üç, dördüncü sınıflarda bir toplamda ise dört olarak karşımıza çıkmaktadır. Bu alan ile ilgili birinci ve ikinci sınıflardan sapma olmamasının sebebi birinci ve ikinci sınıf öğrencilerinin görüşmelerde daha az konuşmalarıdır. Sapma sayısı öğrencilerin Türkçe seviyelerinden ziyade, Türkçe konuşma oranları ile ilgilidir. Türkçe konuşma miktarı arttıkça yapılan sapma sayısı da buna paralel artış göstermektedir. 


\section{İlgi ekinin kullanılmaması}

\section{Sınıflara göre sapma örnekleri:}

Beni (Benim) adım Anesa. (1.sınıf)

Ben (Benim) bir arkadaşım vardı. (3.sınıf)

Yani genelde ben bu Orta Doğu bölgesinden yazarları seviyorum mesela ben Khaled Huseyni (Khaled Huseyni 'nin) kitabını okuyorum. (4.sinif)

Lisede ben Almanca okumak istiyordum fakülteye geldim sormak için ama onlar dediler ki sen (senin) Almanca bilmeniz gerekiyor. (4.sinıf)

İlgi ekinin kullanılmaması ile ilgili sapma sayısı birinci sınıflarda bir, üçüncü sınıflarda bir, dördüncü sınıflarda ise iki toplamda dört olarak karşımıza çıkmaktadır. Diğer sapma türleri ile karşılaştırıldığında bu alanda yapılan sapma sayısı daha az olup sınıflar arasında daha dengeli bir dağılım göstermiştir.

\section{İlgi ve İyelik ekinin kullanılmaması}

\section{Sinıflara göre sapma örnekleri:}

En kolay öğrendiğim şey, sayılar renkler, haftada günler (haftanın günleri). (3.sınıf)

$\mathrm{Bu}$ alanda yapılan sapma sayısı sadece birdir. Bu alanda az sapma yapılmasının sebebi, öğrencilerin bu konuyu daha iyi biliyor olmasından ziyade, görüşme esnasında bu kombinasyonu gerektirecek çok fazla cümle kurmamalarıdır. Çalışmanın devamına bakıldığında iyelik ekinin kullanılmaması ile ilgili yapılan sapma sayısı oldukça yüksektir.

\section{Ayrılma ekinin kullanılmaması}

\section{Sinıflara göre Sapma Örnekleri}

Onu Kurtlar Vadisi (Kurtlar Vadisinden) öğrendim. (4.sınıf)

Şehrimizde bir futbol turnuvası vardı Türkiye'den ve İtalya'dan, birkaç ülkeler(ülkeden) erkeler ve kızlar geldiler.(4. Sinıf)

Ayrılma ekinin kullanılmaması ile ilgili yapılan sapma sayısı iki olup ikisi de dördüncü sınıflar tarafından yapılmıştır. Daha öncede belirtildiği üzere bu durum dördüncü sınıf öğrencilerinin görüşmelerde daha çok konuşmasından kaynaklanmaktadır.

\section{Ad durum eklerinin gereksiz kullanımı}

\section{Sınıflara göre sapma örnekleri:}

Evet, lisede Yunus Emreden (Yunus Emre) tarafindan. (2. Sinıf)

$\mathrm{Bu}$ alanda yapılan sapma sayısı birdir. Yapılan bu sapma sayısına bakılarak öğrencilerin ad durum eklerini gereksiz yere çok kullanmadıkları sonucuna varılabilir.

\section{İsim tamlamasının yanlış kurulması}

\section{Sınıflara göre sapma örnekleri:}

Türkçeye âşık oldum yani benim aşk Türkçe (Türkçe aşkl) 8 yıl önce başladı. (2.sınıf)

$\mathrm{Bu}$ alanda yapılan sapma sayısı birdir. Yapılan bu sapma sayısına bakılarak öğrencilerin isim tamlaması kurma konusunda çok sorun yaşamadıkları sonucuna varılabilir. 


\section{3. İyelik ekleri ile ilgili sapmalar \\ İyelik eklerinin kullanılmaması}

\section{Sınıflara göre sapma örnekleri:}

A: Okulu bitirince ne yapmayı düşünüyorsun?

B: Türk öğretmen (ögrretmeni) ve Türkiye'de çalışmak. (1.sınıf)

A: Okulu bitirince ne yapmayı düşünüyorsun?

B: Umarım Türk ögretmen (ögretmeni) (1.sınıf)

Hayır, Türk kurs (kursu) için zamanım yoktu. (2.sınıf)

İlkokulumda Türkçe kurs (kursu) vardı. (2.sınıf)

Çünkü benim dilde (dilimde) bu sesler yok. (3.sınıf)

Bosna'da ilk Türk dizi (Türk dizisi) Gümüş’tür. (3.sınıf)

Benim okulda Türkçe varmış Türk kurs (kursu) iki yıl kursa gittim. (3.sınıf)

Türkçe hakkında düşünmeye başladım ve beğendim, dili beğendim kültür (kültürü) beğendim bunun için seçtim. (4.sınıf)

Var hangi (hangisi) bilmiyorum hatırlamam ama çok öğrendim. (4.sınıf) (4.sinif)

Ben Türkçe konuşurken duydu ve bana sordu sen benim ögretmeni (ögretmenim) ol.

Türk kültür, Türk halk (Türk kültürünü, Türk halkını) seviyorum. (4.sınıf)

Bence o dünyanın en güzel kültür (kültürrü) Türkiye'nin kültür (kültürü) (4.sınıf)

Tuzla Üniversitede (Tuzla Üniversitesinde) Türkçe bölümü yazdım. (4.sınıf)

Zaten İngilizce biliyorum. Almanca pek sevmiyorum ve Türkçe öğreniyorum ve Türk kültürü (kültürü), insanlar (insanları) ile tanışmak istiyorum. (4.sınıf)

Türkçe hakkında düşünmeye başladım ve beğendim, dilini beğendim kültür (kültürünü) beğendim bunun için seçtim. (4.sinıf)

Türk kültür, Türk halk (Türk kültürünü, Türk halkını) seviyorum. (4.sınıf)

İyelik eklerinin kullanılmaması ile ilgili sapma birinci sınıflarda iki, ikinci sınıflarda iki, üçüncü sınıflarda üç, dördüncü sınıflarda on üç olmak üzere toplamda yirmidir. Bu belirtme ekinin kullanılmaması ile ilgili yapılan sapma sayısından sonraki en yüksek sayıdır. Sınıflara göre baktığımızda daha önce bahsedilen sebepten dolayı dördüncü sınıflarda yapılan sapma sayısı en yüksektir. Ancak bu alanda tüm sınıfların sapma yapmış olduğu da dikkatlerden kaçmamalıdır. Bu sebeple Türkçenin yabancı dil olarak öğretiminde iyelik ekleri konusu üzerinde daha özenli ve daha uzun durulmalıdır. Öğrencilere iyelik eklerinin nerede, ne zaman ve nasıl kullanacağı konusu çok iyi anlatılmalı ve bu konu ile ilgili mümkün olduğunca mekanik, anlamlı ve iletişimsel alıştırmalar yaptırılmalidir.

\section{İyelik ekinin gereksiz kullanımı}

\section{Sınıflara göre sapma örnekleri:}

Fakülteye önce hiç konuşmadım ama dizisi (dizi) izledim. (2.sınıf)

Ben o zaman 11 -12 yaşındaydım ve ben o kursuna (kursa) gittim. (2.sınıf) 
Bosna Hersek Federasyonu Tuzla Üniversitesi Türkoloji Bölümü Öğrencilerinin Yaptıkları... 2077

Türk insanları Bosna'da bazı işler yapıyorlar bunun için daha kolay işim (iş) bulacağım belki.(4.sinif)

İyelik eklerinin gereksiz kullanımı ile ilgili sapma sayısı ikinci sınıflarda iki, dördüncü siniflarda bir toplamda ise üçtür.

\subsection{Bildirme çekimi ile ilgili sapmalar}

\section{Bildirme ekinin kullanılmaması}

\section{Sinıflara göre sapma örnekleri:}

Türkçe tabi ki çünkü dört yıl (yıldır) öğreniyorum ders çalışıyorum. (4.sınıf)

$\mathrm{Bu}$ alanda yapılan sapma sayısı birdir.

\section{Bildirme ekinin gereksiz kullanılması}

\section{Sinıflara göre sapma örnekleri:}

Bence Türkçe zor değildir. (değil) (3.sınıf)

$\mathrm{Bu}$ alanda yapılan sapma sayısı birdir.

Bildirme çekimi ile ilgili yapılan sapma sayılarına baktığımızda oldukça düşüktür. Buradan öğrencilerin bildirme çekimi ile ilgili olarak çok fazla sorun yaşamadıkları sonucuna varılabilir.

\section{5 Çekimde kullanılan kişi ekleri ile ilgili sapmalar}

\section{Kişi eklerinin yanlış ya da eksik kullanımı}

\section{Sinıflara göre sapma örnekleri:}

Ben folklor oynuyorum, İzmir'de gitti. (gittim) (1.sınıf)

Levent kurs adı orda gitti (gittim). (2.sinıf)

İlk defa fakültede 1. sınıftayım Türkiye'den öğretmenlerimiz geldik.(geldi) (4.sınıf)

Öğrenci Türkiye'den gelince bizimle kafede geldik (geldi) ve biraz konuştuk. (4.sınıf)

A: Okulu bitirince ne yapacaksın?

B: Şimdi bilmiyorum belki öğretmen olacak (olacağım) ama burada değil. (4.sınıf)

Kişi eklerinin yanlış ya da eksi kullanımı ile ilgili sapma sayısı birinci sınıflarda bir, ikinci sınıflarda bir, dördüncü sınıflarda üç toplamda ise beş olarak karşımıza çıkmaktadır. Dördüncü sınıflarda sapma sayısını çok olmasının sebebi daha önceki başlıklarda açıklanmıştır.

\section{Fiil çekimi ile ilgili sapmalar}

\section{Yanlış zaman seçimi}

\section{Sınıflara göre sapma örnekleri:}

Ben Türkiye'de Türkiye gidiyorum. (gittim) ve çok beğendim. (2.sınıf)

A: Türkçe öğrenirken yaşadığın komik bir olay var mı?

S: Şimdi hatırlamam (hatırlamıyorum) ama var. (2.sınıf)

Ben fakülteye önce kurstan giderim (gittim). (2.sınıf)

Lisede çok diller okudum, Fransızca, Almanca, Latince ama bir şey değişmek istiyorum (istedim). (2.sinif)

Var ama hatırlamadım (hatırlamıyorum) şimdi. (4.sınıf) 
Emina böyle söyledi adam bana bakıyor (baktı) anlamadı ne söylemek istedi.(4.sınıf)

Ben Türkiye'ye gittim ve hala iyi konuşamam (konuşamıyorum) ( (4.sınıf)

Çok hatırlamadım (hatırlamıyorum) şimdi ama belki lisedeyken (4.sınıf)

Yemekleri ile ilgili çok şey gördüm ama yemekleri hiç sevmiyordum(sevmedim). (4.sınıf)

Dizileri takip ettim o yüzden böyle evet çok ilginç bir dil falan dedim, öğrenmek istiyorum (istedim) (4.sinif)

Ben ilk önce Boşnakça ve Edebiyatı Bölümünde okuyordum ama sonra böyle kararımı verdim. Türkçe öğrenmek istiyorum (istedim) (4.sınıf)

Yanlış zaman seçimi ile ilgili yapılan sapma sayısı ikinci sınıflarda dört, dördüncü siniflarda yedi toplamda on birdir. Bu alanda birinci ve ikinci siniflarda herhangi bir sapmaya rastlanmamıştır.

\section{Yeterlilik kipinin kullanılmaması}

Sınıflara göre sapma örnekleri:

Hatırlamadım (Hatırlayamadım) gerçekten. (3.sınıf)

Evet, ben çok düşünüyordum ama bulmadım (bulamıyordum). (3.sınıf)

Ben Türkiye'ye gittim ve hala iyi konuşamam (konuşamıyorum) (4.sınıf)

Yeterlilik kipinin kullanılmaması ile ilgili sapma sayısı üçüncü sınıflarda iki, dördüncü sınıflarda bir toplamda üç olarak karşımıza çıkmaktadır. Buradan yeterlilik kipinin doğru kullanımının öğrenciler için çok büyük bir sorun yaratmadığı sonucuna varılabilir.

\section{Şart kipinin kullanılmaması}

\section{Sınıflara göre sapma örnekleri:}

Eğer seviyorlar (seviyorlarsa) tavsiye ediyorum ama eğer sevmiyorlar (sevmiyorlarsa) o zaman tavsiye etmiyorum çünkü eğer bir şeyi öğrenmek istiyorsunuz (istiyorsanız) o zaman sevmeniz gerekiyor. (3.sinıf)

Bu alanda yapılan sapma sayısı üçüncü sınıfta aynı öğrenci tarafından kurulmuş cümlede üç olarak karşımıza çıkmaktadır. Buradan şart kipinin doğru kullanımının öğrenciler için çok büyük bir sorun yaratmadığg sonucuna varılabilir.

\section{Birleşik zaman çekiminin kullanılamaması}

\section{Sınıflara göre sapma örnekleri:}

En iyi kim yaparsa o İstanbul'a gidecek (gidecekti). (2.sinıf)

Evet, ben çok düşünüyordum ama bulmadım (bulamıyordum). (3.sınıf)

Tamam, yani daha önce bilmedim (bilmiyordum).(4.sinıf)

$\mathrm{Bu}$ alanda yapılan sapma sayısı ikinci sınıflarda bir, üçüncü sınıflarda bir, dördüncü sınıflarda bir toplamda üçtür. Sınıfta yapılan gözlemler ve yaşanan tecrübeler neticesine birleşik zamanın doğru kullanımının öğrenciler için sorun olduğu söylenebilir. Çalışmada bu alanda az sapma yapılmış olmasının sebebi, öğrencilerin birleşik zamanlı cümleler kurmalarını gerektirecek bir durumun ortaya çıkmaması ya da öğrencilerin bundan özellikle kaçınmış olmalarıdır. 


\section{Yapım ekleri ile İlgili sapmalar}

\section{Addan ad yapım ekinin kullanılmaması}

\section{Sınıflara göre sapma örnekleri:}

A: Okulu bitirince ne yapmayı düşünüyorsun?

B: Türk (Türkçe) öğretmen ve Türkiye'de çalışmak. (1.sınıf)

A: Okulu bitirince ne yapmayı düşünüyorsun?

B: Umarım Türk (Türkçe ) öğretmen (1.sınıf)

Hayır, Türk (Türkçe) kurs için zamanım yoktu. (2.sınıf)

S: Yok hiç çalışmadım bu gün yağmur (yağmurlu) hava çok soğuk ve ben hissetmiyorum(2.sinif)

Türk (Türkçe) kursuna gittim. (3.sınıf)

Orada asker (askerlik) yapt1. (3.sinif)

Evet, ama biraz zor o yüzden tercüman (tercümanlık) zor. (3.sinıf)

Benim okulda Türkçe varmış Türk (Türkçe) kurs iki yıl kursa gittim. (3.sınıf)

Kursta yani Türk (Türkçe) kursuna gittim. (3.sınıf)

Tercüman (Tercümanlık) çok zor benim için(4.sınıf)

Addan ad yapım ekinin kullanılmaması ile ilgili sapma sayısı birinci sınıflarda iki, ikinci sinıflarda iki, üçüncü sinıflarda beş, dördüncü sınıflarda bir toplamda ise ondur. Burada dikkat çeken durum bu sapmanın üçüncü sınıflar tarafından daha fazla yapılmış olmasıdır. Derste yapılan gözlemler, deneyimler ve buradaki sonuçlara göre addan ad yapım ekinin kullanımının öğrenciler için sorunlu bir alan olduğu söylenebilir.

\section{Çatı eklerinin kullanılamaması}

\section{Sinıflara göre sapma örnekleri:}

Lisede çok diller okudum, Fransızca, Almanca, Latince ama bir şey değişmek (değiştirmek) istiyorum. (2.sinıf)

$\mathrm{Bu}$ alanda yapılan sapma sayısı birdir. Bunun sebebi öğrencilerin çatı eklerini çok iyi anlamaları değildir. $\mathrm{Bu}$ durum öğrencilerin çatı eki gerektiren cümleler kurmaktan kaçınmaları ya da konuşmalarında çatı eki kullanımını gerektirecek bir durumun ortaya çıkmamasıdır. Derste yapılan ve gözlemlerden öğrencilerin çatı eklerini doğru kullanmaları konusunda ciddi sorunlar yaşadıkları söylenebilir.

\section{Fiilimsiler ile ilgili sapmalar}

İsim fiil eklerinin birbirinin yerine kullanılması

\section{Sınıflara göre sapma örnekleri:}

A: Hangi dilleri biliyorsun?

B: İngilizce ve biraz Arapça ama sadece okumak ve yazmak (okuma ve yazma), konuşmak (konuşma) yok (3.sinıf)

Her şeyi söyleme (söylemek) zor değil ama bazen ö-ü zor geliyor (3.sınıf)

Seviyorum Türkiye'yi, dizileri seviyorum dilleri seviyorum okumak (okumayl) (ve bunu seçtim (4.sinıf) 


\section{Evet, biraz oldu seviyorum Türkçeyi dinlemek (dinlemeyi) (4.sınıf)} dörttür.

$\mathrm{Bu}$ alanda yapılan sapma sayısı üçüncü sınıflarda iki, dördüncü sınıflara iki toplamda ise

\section{Sıfat fiil ekinin yanlış kullanımı}

\section{Sınıflara göre sapma örnekleri:}

A: Geçen hafta neden derse gelmedin?

B: Geldikleri (Gelenler) bana ders olmadığını söyledi. (3.sınıf)

Evet, mesela Türkiye'ye ilk gittiğimde geçen yıl ben biz bir plaja gittik ve sandalyeler şezlong ve ben bir cümle kurmaya çalıştıkça şu adam plajda çalıştığl (plajda çalışan) adam Boşnakçada biliyordu(4.sınıf)

Bu alanda yapılan sapma sayısı üçüncü sınıflarda bir, dördüncü sınıflarda bir toplamda ise ikidir. Fiilimsilerin kullanımı alanında yapılan sapma sayısının az olmasının sebebi öğrencilerin fiilimsileri kullanmaktan kaçınmalarından kaynaklanmaktadır. Öğrenciler fiilimsileri kullanmak yerine tek bir cümleyi ikiye bölerek ifade etme yolunu seçmektedirler. Örneğin "Ne yapacă̆ımı bilmiyorum." cümlesini ikiye bölüp "Bilmiyorum. Ne yapacağım?" şeklinde ifade etmektedirler. Bu tür cümle kullanımlarına derste sıklıkla karşılaşılmıştır. Bu sebeple fiilimsilerin kullanımında yapılan sapma sayısı az olarak karşımıza çıkmıştır.

Yukarıda örnekler ile gösterilen sapma türleri, sapma sayıları ve yapılan sapmaların sınıflara göre dağılımı aşağıdaki şekilde tablo haline getirilmiştir.

\begin{tabular}{|c|c|c|c|c|c|}
\hline \multirow[t]{2}{*}{ Biçim Bilgisel Sapma Türleri } & \multirow{2}{*}{$\begin{array}{c}\text { Sapma } \\
\text { Sayısı }\end{array}$} & \multicolumn{4}{|c|}{$\begin{array}{c}\text { Sapma Sayılarının Sınıflara Göre } \\
\text { Dağılımı }\end{array}$} \\
\hline & & 1.sınıf & 2.sınıf & 3.sınıf & 4.sınıf \\
\hline 1- Coğul ekinin kullanılmaması & 1 & & 1 & & \\
\hline 2- Coğul ekinin gereksiz kullanımı & 5 & & 3 & & 2 \\
\hline 3- Yönelme ekinin kullanılmaması & 4 & & & 1 & 3 \\
\hline 4- Belirtme ekinin kullanılmamas1 & 27 & 6 & 4 & 6 & 11 \\
\hline 5-Ad durum eklerinin birbirinin yerine kullanılması & 20 & 2 & 10 & 5 & 3 \\
\hline 6- Araç ekinin kullanılmaması & 4 & & & 3 & 1 \\
\hline 7- İlgi ekinin kullanılmaması & 4 & 1 & & 1 & 2 \\
\hline 8- İlgi ve İyelik ekinin kullanılmaması & 1 & & & 1 & \\
\hline 9- Ayrilma ekinin kullanılmamas1 & 2 & & & & 2 \\
\hline 10- Ad durum eklerinin gereksiz kullanımı & 1 & & 1 & & \\
\hline 11- İsim tamlamasının yanlıs kurulması & 1 & & 1 & & \\
\hline 12- İyelik eklerinin kullanılmaması & 20 & 2 & 2 & 3 & 13 \\
\hline 13- Iyelik ekinin gereksiz kullanımı & 3 & & 2 & & 1 \\
\hline 14- Bildirme ekinin kullanılmamas1 & 1 & & & & 1 \\
\hline 15- Bildirme ekinin gereksiz kullanılması & 1 & & & 1 & \\
\hline 16- Kişi eklerinin yanlış ya da eksik kullanımı & 5 & 1 & 1 & & 3 \\
\hline 17- Yanlış zaman seçimi & 11 & & 4 & & 7 \\
\hline 18- Yeterlilik kipinin kullanılmaması & 3 & & & 2 & 1 \\
\hline 19- Şart kipinin kullanılmaması & 3 & & & 3 & \\
\hline 20- Birleşik zaman çekiminin kullanılamaması & 3 & & 1 & 1 & 1 \\
\hline 21- Addan ad yapım ekinin kullanılmamas1 & 10 & 2 & 2 & 5 & 1 \\
\hline 22- Catı eklerinin kullanılamaması & 1 & & 1 & & \\
\hline 23- İsim fiil eklerinin birbirinin yerine kullanılması & 4 & & & 2 & 2 \\
\hline 24- Sıfat fiil ekinin yanlıș kullanımı & 2 & & & 1 & 1 \\
\hline Toplam Sapma Sayısı & 137 & 14 & 33 & 35 & 55 \\
\hline
\end{tabular}


Alan yazına bakıldığında Türkçeyi yabancı dil ya da ikinci dil olarak öğrenen yabancıların biçim bilgisel anlamda yaptığı sapma ya da hataları tespit etmeye yönelik çok fazla çalışma bulunmamaktadır. $\mathrm{Bu}$ alanda yapılmış olan çalışmalara bakıldığında Türkçeyi yabancı dil olarak öğrenen öğrencilerin biçim bilgisel anlamda en çok zorlandıkları konunun ad durum eklerinin doğru kullanımı olduğu görülmektedir. Örneğin, Karababa (2009:273) çalışmasında yabancıların Türkçe öğrenirken en çok zorlandığı konulardan birinin de eklerin kullanımı olduğunu özellikle belirtme durum ekini kullanmada yabancı öğrencilerin zorlandıklarını belirtmiştir. Ayrıca Karababa (2009:273) Türkçenin yabancı dil olarak öğretildiği sınıflarda yapılan gözlem ve araştırmalar sonucunda ad durum eklerinin kullanımında yapılan yanlışların Türkçenin yabancı dil olarak öğretiminde önemli bir yer tuttuğunu ifade etmiştir. Bu tespite ek olarak ad durum eklerinin öğretimi ile ilgili öğrencilerin yazılı metinlerini tarayarak yaptığı çalışmasında Karaba'nın (2009:274) aktardığına göre Özkan(1994: 40) belirlediği yanlış türlerini şu 5 ana başlık altında toplamıştır.

\section{Ad durum ekinin kullanılmamas1, \%52,7}

2. Ad durum ekinin gereksiz olarak kullanılması, \%21,9

3. Kullanılması gereken ad durum eki yerine başka bir ad durum ekinin kullanılması, $\% 25,4$

4. Ad durum eklerinin ünlü, ünsüz uyumlarına göre yanlış kullanılması.

5. Ad durum eklerinin cümlenin yanlış ögesinde (öznede) kullanılması.

Bu çalışmalara ek olarak Chang(2016:45) Türkçeyi yabancı dil olarak öğrenen öğrencilerin karşılaştıkları sorunlar ile ilgili çalışmasında Tayvanlı öğrencilerin Çincenin yapısından kaynaklı olarak biçim bilgisel anlamda genellikle ismin halleri, duyulan (öğrenilen) zaman kipi, geniş zaman kipi, ettirgen çatı, edilgen çatı, dönüşlü fiiller konusunda sorun yaşadıklarını tespit etmiştir. Polat (1998: 67) Arapların Türkçe öğrenirken karşılaştıkları sorunlar adlı çalışmasında Arapların biçim bilgisel olarak hal eklerini kavramakta zorlandıklarını ortaya koymuş bunun sebebi olarak da Arapçada hal eklerinin isimden önce, fiilden sonra geldiğini belirtmiştir. Bu çalışmaya benzer bir çalışma Kara (2010) tarafindan yapılmıştır. Bu çalışmasında Kara (2010:671) Gazi Üniversitesi TÖMER'e farklı ülkelerden ve bölgelerden gelen toplam 1324 öğrencinin kendilerine özgü hangi temel hataları yaptıkları sorusuna cevap aramıştır. Öğrencilerin yaptıkları dil bilgisi hatalarını örnekleriyle sıralamış ve biçim bilgisel olarak öne çıkan şu hataları tespit etmiştir.

1. Yeterlilik fiilinin olumsuzunun yanlış kullanılması

2. Belirtme hâli eki ile yönelme hâli ekinin birbirinin yerine kullanılması

3. Özellikle iyelik ekinin kullanıldığı kelimelerde belirtme hâli ekinin kullanılmaması

4. Yönelme hâli eki yerine bulunma hâli ekinin kullanılması

5. Şahıs zamirinin kullanıldığı cümlelerde, yüklemde şahıs ekinin kullanılmaması

6. Belirtili veya belirtisiz isim tamlamalarında iyelik ekinin yazılmaması bilinememesi

7. Hangi kelimelerin belirtili isim tamlaması veya belirtisiz isim tamlaması olacağının

8 Fiil cümlelerinde olumsuzluk eki olarak "değil” ve "yok" kelimelerini kullanılması

9. Şahıs zamirlerine -in ilgi hâlinin getirilmesi

10. Belirtili isim tamlamalarında iyelik ekini iki defa kullanılması

11. Her, hepsi, birçok, çok gibi anlam olarak çokluk bildiren belirsizlik sıfatlarından veya zamirlerinden sonra gelen isimlere çokluk eki getirilmesi 
Son olarak Şahbaz (2018: 423) Fethiye'de yaşayan ve Türkçe bilen İngilizlerin Türkçe konuşurken yaptıkları biçim bilgisel sapmalar üzerine yaptığı çalışmasında 28 biçim bilgisel sapma tespit etmiş ve şu sonuçları elde etmiştir.

1. Katılımcıların yaklaşık yarısı konuşurken Türkçe çoğul eklerini kullanmamışlardır.

2. Ad durum eklerinin doğru kullanılmaması katılımcıların en büyük biçim bilgisel sorunudur.

3. Katılımcılar iyelik eklerini kullanma konusunda sorun yaşamaktadır.

4.Katılımcılar bildirme çekim ekini doğru kullanamamaktadır.

5.Katılımcıları kişi eklerinin yanlış ya da eksik kullanmaktadır.

6. Katılımcılar özellikle fiilin sonuna getirilen kip, zaman, kişi eklerini doğru biçim ve sirada kullanamamaktadır.

7. Katılımcılar yapım ekleri konusunda da genellikle addan ad yapım ekleri ile çatı eklerinde sorun yaşamaktadır.

\section{Sonuçlar ve öneriler}

$\mathrm{Bu}$ çalışmada, yukarıdaki tabloda da gösterildiği üzere toplam 24 çeşit biçim bilgisel sapma tespit edilmiştir. Toplam sapma sayısı 137 olup bu sayılar birinci sınıflar için 14, ikinci sınıflar için 33, üçüncü sınıflar için 35, dördüncü sınıflar için ise 55’tir.

Sapma sayılarına bakıldığında en fazla sapmayı sırasıyla dördüncü, üçüncü, ikinci ve birinci sınıflar yapmıştır. Burada dikkat çeken konu, en fazla sapma sayısının dördüncü sınıf öğrencileri tarafından yapılmış olmasıdır. Bunun sebebi dördüncü sınıf öğrencilerinin birinci sınıf öğrencilerinden daha az Türkçe biliyor olmaları değil, görüşmelerde en çok Türkçe konuşan grup olmalarıdır. Konuşma oranı arttıkça sapma sayısı artmış, konuşma oranı azaldıkça sapma sayısı da azalmıştır.

En yüksek biçim bilgisel sapma 27 ile belirtme ad durum ekinin kullanılmaması alanında yapılmıştır. Bunu 20'şer sapma ile ad durum eklerinin birbirinin yerine kullanılması ve iyelik eklerinin kullanılmaması takip etmiştir. Yanlı̧̧ zaman seçimi ile ilgili 11, addan ad yapım ekinin kullanılmaması ile ilgili ise 10 adet sapma yapılmıştır. Diğer alanlarda yapılan sapma sayıları 1 ile 5 arasında değişiklik göstermektedir.

Sonuçlara bakıldığında en fazla sapmanın ad durum ekleri alanında yapıldığ görülmektedir. Ad durum eklerinin içinde ise belirtme ekinin kullanılmaması ile ilgili sapma sayısı en yüksek olandır. Bir önceki bölümde biçim bilgisel sapmalar üzerine yapılan çalışmalardan elde edilen sonuçlar paylaşılmıştır. Bu çalışmalardaki sonuçlar ile buradaki sonuçlar benzerlik göstermektedir. Yaptıkları çalışmalarda Karababa, Chang, Özkan, Kara ve Şahbaz Türkçe öğrenen yabancıların en çok ad durum eklerinin doğru kullanımı konusunda sorunlar yaşadıklarını tespit etmiş̧lerdir. Bu sebeple genelde ad durum eklerini öğretirken özellikle de belirtme ad durum ekini öğretirken daha dikkatli olunmalı, bu konu üzerinde daha fazla durulmalı, öğrencilere daha fazla alıştırma ve pratik yaptırılmalıdır.

Ad durum ekleri alanında yapılan sapmaları iyelik ekleri ile ilgili yapılan sapmalar takip etmektedir. Bu çalışmada bazı öğrencilerin adlardan sonra iyelik eki kullanmadıkları tespit edilmiştir. Şahbaz'da (2018: 423) Türkçe bilen İngilizler ile yürüttüğü çalışmasında bazı İngilizlerin de konuşurken iyelik eki kullanmadığını tespit etmiştir. Bunun sebebi hem İngilizce de hem de Boşnakça da isimlerden sonra iyelik ekinin kullanılmaması ve ana dilden kaynaklanan bu özelliğin Türkçeye kopyalanması olabilir. Bu sebeple Türkçeyi yabancı dil olarak öğretirken iyelik eklerinin nerede, ne zaman ve nasıl kullanacağı konusu öğrencilere çok iyi anlatılmalı ve bu konu ile ilgili mümkün olduğunca mekanik, anlamlı ve iletişimsel alıştırmalar yaptırılmalıdır. 
Yanlış zaman seçimi ve addan ad yapım ekinin kullanılmaması diğer dikkat çeken biçim bilgisel sapma türüdür. Benzer şekilde Türkçe zamanlar ve addan ad yapım eklerinin öğretilmesi konuları üzerinde de özenle durulmalıdır.

Her ne kadar çalışmada, birleşik zaman kullanımı ile ilgili yapılan sapma sayısı az görünse de sınıfta yapılan gözlemler neticesine birleşik zamanın doğru kullanımının öğrenciler için sorun olduğu söylenebilir. Çalışmada bu alanda az sapma yapılmış olmasının sebebi öğrencilerin birleşik zamanlı cümleler kurmalarını gerektirecek bir durumun ortaya çıkmaması ya da öğrencilerin bundan özellikle kaçınmaları olabilir. Bu sebeple Türkçeyi yabancı dil olarak öğretirken birleşik zaman kullanımı konusunun üzerinde de özenle ve dikkatle durulmalıdır.

Sonuçlara baktığımızda çatı ekleri ve fiilimsiler konusunda yapılan sapma sayılarının az olduğu görülmektedir. $\mathrm{Bu}$ alanlar ile ilgili sapmalar az olsa da derslerde öğrencilerin çatılar ve fiilimsilerin doğru kullanımları ile ilgili ciddi hatalar yaptıkları gözlemlenmiştir. Bu çalışmada, bu alanlar ile ilgili az sapma sayısının az olmasının sebebi öğrencilerin görüşmelerde çatı ve fiilimsileri bilerek ya da bilmeyerek kullanmaktan kaçınmalarıdır. Ayrıca, birinci ve ikinci sınıf öğrencilerinin Türkçe seviyeleri çatı ve fiilimsileri kullanabilecek seviyede değildir. Birinci ve ikinci sınıf öğrencileri bu yapıları kullanmadığı için hata da yapmamışlardır. Üçüncü ve dördüncü sınıf öğrencilerinin çoğunluğu ise fiilimsi gerektiren cümleleri ikiye bölerek ifade etme yolunu seçmişlerdir. Örneğin bazı öğrenciler zarf fiil eki $D X \breve{g} X$ kullanımını gerektiren "İstanbul' $a$ gittiğimde, insanlarl çok sevdim." cümlesini ikiye bölerek "Ístanbul'a gittim. Ínsanları çok sevdim." ş̧eklinde ifade etmişlerdir. İşte bu sebeple yani fiilimsilerin kullanımını gerektiren cümleler ikiye bölünerek ve dolayısıyla dil bilgisel hata yapılmadan söylendiği için bu alanda yapılan sapma sayısı az olarak karşımıza çıkmaktadır. Ayrıca bu çalışmada öğrencilere en çok zorlandıkları dilbilgisi konusun ne olduğu sorulmuş ve dördüncü sınıf öğrencilerinin yarısı fiilimsileri ve edilgen/ ettirgen yapıyı zor bulduklarını ifade etmişlerdir. Chang'da (2016:45) Türkçeyi yabancı dil olarak öğrenen öğrencilerin karşılaştıkları sorunlar ile ilgili yaptığı çalışmasında Tayvanlı öğrencilerin ettirgen çatı, edilgen çatı konusunda sorun yaşadıklarını tespit etmiştir. Bu sebeple, Türkçenin yabancı dil olarak öğretiminde çatı ve fiilimsi konularının da üzerinde daha dikkatli ve özenli durulmalıdır.

$\mathrm{Bu}$ çalışmadan elde edilen sonuçların Türkçenin yabancı dil olarak öğretimi alanında hazırlanacak olan materyal ve müfredata 1 şı tutacağı düşünülmektedir.

\section{Kaynakça}

Balc1, A. (2012). Biçim Bilim I. S. Özsoy, Z. Erk Ekmeksiz (Ed.), Genel Dilbilim I (2.bs). (ss.1835). Anadolu Üniversitesi Açı Öğretim Fakültesi Yayını

Banguoğlu, Tahsin. (1974). Türkçenin Grameri (2.bs). Türk Tarih Kurumu Basım Evi

Başdaş, Cahit (2006), "Türkçede Üçüncü Grup (Ara) Ekler”, I. Uluslararası Büyük Türk Dili Kurultayl, 26-27 Eylül 2006, Bilkent Üniversitesi, 1-6.

Chang, W. (2016). Tayvan'da Yabancı Dil olarak Türkçenin Öğretiminde Karşılaşılan Sorunlar ve Çözüm Önerileri. Yüksek Lisans Tezi, Gazi Üniversitesi.

Delice, İ. (2000). Türk Dilinde İşlevsel Ek Tasnifi Denemesi. Cumhuriyet Üniversitesi Sosyal Bilimler Dergisi, (24), 221-234

Demir, N. (2015). Temel Kavramlar. H. Pilancı (Ed.). Türkçe Biçim Bilgisi(1.bs). (ss. 2-25). Anadolu Üniversitesi Web-Ofset.

Demirci, K. (2014). Türkoloji için Dilbilim. (2.bs). Anı Yayıncılık 
Erdem, M. (2009). Biçim Bilgisi. N. Demir, E. Yılmaz (Ed.) Türk Dili Yazılı ve Sözlü Anlatım(1.bs). (ss. 91-107) Nobel Yayın

Ergin, M. (1987). Üniversiteler için Türk Dili.(3.bs). Bayrak Basım

Gencan, N. (1979). Dilbilgisi. (4.bs). Türk Dil Kurumu Yayınları

Kara, M. (2010). Gazi Üniversitesi TÖMER Öğrencilerinin Türkçe Öğrenirken Karşılaştıkları Sorunlar ve Bunların Çözümüne Yönelik Öneriler. Türk Eğitim Bilimleri Dergisi, (8), 661696,

Karababa, C. (2009). Yabancı Dil Olarak Türkçenin Öğretimi ve Karşılaşılan Sorunlar. Ankara Üniversitesi Eğitim Bilimleri Fakültesi Dergisi, (2), 265-277.

Korkmaz, Z. (2014). Türkiye Türkçesi Grameri Şekil Bilgisi (4.bs). Türk Dil Kurumu Yayınları

Özkan, A. (1994). Yabancı Dil Olarak Türkçe Öğretiminde Ad Durum Eklerinin Öğretilmesiyle İlgili Kimi Görüşler. $A \ddot{U}$ TÖMER Dil Dergisi, (17), 40-52

Polat, H. (1998). Arapların Türkçe Öğrenirken Karşılaştıkları Sorunlar. Yüksek Lisans Tezi, Ankara Üniversitesi.

Şahbaz, A. (2018). Fethiye'de Yaşayan Yetişkin İki Dilli İngilizlerin Yaptıkları Türkçe Biçim Bilgisel Sapmalar. Turkish Studies, (13), (400-426), https://doi.org/10.7827/turkishstudies.13140 